\title{
Land Index and Production of Arabica Coffee (Coffea Arabica L.) in Smallholding Plantation of Tana Toraja District, Indonesia
}

\author{
Salapu Pagiu*, Ramlan, Tresensia Irna Belo, Yosep S. Patadungan \\ Faculty of Agriculture, Tadulako University, Palu 94118, Indonesia
}

Corresponding Author Email: salapupagiu@ aol.com

https://doi.org/10.18280/ijdne.150417

Received: 10 April 2020

Accepted: 24 June 2020

\section{Keywords:}

land suitability class, land index, Arabica

coffee, production, income

\begin{abstract}
This study aimed to evaluate the suitability of Arabica coffee plantations and analyze the relationship between land suitability index and Arabica coffee production. This study used quantitative methods conducted by direct surveys in Arabica coffee plantations in Tana Toraja District, South Sulawesi. The analysis of land suitability was performed using a parametric approach with the Storie Index equation. Then it followed by an analysis of the correlation between land suitability index and Arabica coffee productions using a coefficient of determination and economic analysis. The results showed that the plant growth time of Arabica coffee plantations in the humid tropics relatively dry lasts from June to September 2019. Plantation land has a flat to hilly topography, fine texture, good drainage, shallow to deep solum, slightly acidic $\mathrm{pH}$, moderate cation exchange capacity and wet saturation, and moderate organic matter content. Land suitability for Arabica coffee plants in the study location was quite appropriate (S2) and marginally appropriate (S3), respectively in Pasang and Parindingan Villages with limiting factors of topographic, $\mathrm{pH}$, and temperature. Land suitability index in the study location ranged from 32.21 to 50.12; Arabica coffee production ranged from 6 to 8 tons per hectare. The coefficient of determination (R) between the land suitability index and Arabica coffee production was one. It indicates the strength of the correlation between land suitability index and Arabica coffee production. It has proven the land suitability index can be used as a potential predictor of Arabica coffee in the Tana Toraja Regency. Arabica coffee farmers' net income was around IDR 129,900,000-117,797,000 with an R / C ratio ranging from $4.41-6.02$.
\end{abstract}

\section{INTRODUCTION}

Land evaluation is an approach or a way to assess the potential of land resources $[1,2]$. The results of the land evaluation will provide information and directions for land use. Climatic and physical / chemical factors can influence land evaluation. Climatic factors such as temperature, rainfall, humidity, and irradiation time, while physical/chemical elements are topography, drainage, solum depth, erosion, flooding, soil texture, nitrogen, phosphorus, potassium, organic matter, soil acidity, ion exchange capacity, and saturation wet. Of all climate/soil factors, it is following on numerical figures from a minimum of 0 (zero) to a maximum of $100 \%$, which is formulated by multiplying to produce a land index to determine land suitability classes $[3,4]$. High slope on plantation land will affect crop production due to erosion so that it can reduce soil productivity [5].

A land potential index provides information on land use in accordance with the potential and land resources [2]. Data on the potential of agricultural land becomes essential to evaluate the suitability of agricultural land. The high or low potential of land can be determined, from several supporting parameters, the higher the potential index of land, the higher the potential land use [6].

The development must pay attention to the potential of the land to be built. Site selection is critical to maintaining a high potential area as agricultural land. High potential land has high productivity. Coffee crop production is caused by a favorable climate condition, superior plant varieties, proper management of the land, and planting areas resulting in the production of coffee plants [7].

Appropriate land selection requires methods and evaluating system of land suitability that are actual and more reliable, as guidance in land management efforts to achieve average productivity [8]. The coffee plantations in Tana Toraja are operated by society to date by conventional models and are generally intensively controlled, by clearing slopes and using chemical processing facilities in its maintenance and care. This condition provides an unfavorable response to coffee productivity and sustainable trading in the present and future [9].

Generally, the issue of coffee in Indonesia is managing the Robusta and Arabica coffee plantation concurrently. Robusta coffee plants dominate the suitable land for growing Arabica coffee. Robusta coffee is older, and the price is lower compare to Arabica coffee, which has a higher selling value [10]. Areas that produce Arabica coffee include North Sumatra, Aceh, East Java, Bali, East Nusa Tenggara, and so forth. Indonesia is the fourth producer in the world for coffee producers today.

Therefore, the authors conducted a study, evaluating the suitability of land for Arabica coffee plants, with a storie index method based on numerical figures on each of the growth requirements of Arabica coffee plants (Coffea arabica L.) at two Smallholding Plantation Located in the Parindingan and 
Pasang Villages in Toraja".

This study aims to determine the land index and the production of Arabica coffee (Coffea Arabica L.) in two smallholding crops of the Parindingan Village and Pasang Village in Toraja.

\section{MATERIALS AND METHODS}

The study used the FAO land suitability evaluation survey method (limit method) based on climate data, classified according to the Schmidt and Ferguson climate types; soil fertility data including chemical and physical properties were evaluated. The land evaluation method used was a parametric approach based on the numerical value of land using the Storie Index obtained by transferring values from several specific factors. It conducted by giving numerical numbers from 0 (minimum) to 100 (maximum) for each land characteristics/quality depending on the requirements of the plants would be cultivated.

In obtaining the land suitability classes for Arabica coffee plants in Parindingan and Pasang Villages of Tana Toraja, the climate data from field observations and laboratory analysis results were then multiplied to find the Land Index. From that result would determine the land suitability class for Arabica coffee plants by technical instructions for evaluating agricultural land [1]. Land characteristics observed include environment (rainfall, humidity, air temperature), drainage, abrasive (percentage), solum depth $(\mathrm{cm})$, and erosion hazards measured according to the USLE system, inundation, surface rock (\%), rock outcrop (\%), CEC (me / $100 \mathrm{~g}$ ) pH $7 \mathrm{NH}_{4} \mathrm{Oac}$ extraction method, $\mathrm{pH} \mathrm{H}_{2} \mathrm{O}$ electrometry method (1:25), wet saturation (\%) of $\mathrm{NH}_{4}$ Astat $1 \mathrm{~N} \mathrm{pH} \mathrm{7,} \mathrm{C-organic} \mathrm{( \% )} \mathrm{Welkey}$ and Black method, and texture pipette method. Land Suitability Classification is divided into three namely S1 (Very Appropriate), S2 (Sufficiently Appropriate), and S3 (Marginal Appropriate) [11].

Analysis of climate data in Arabica coffee plant-soil used parametric approach to land evaluation Storie method based on the value of the land index, climate, and limiting factors [1]. Land elements, a climate that is important for each plant, were given a value based on the ecovalence as well as determining the land boundary level, which was characterized by a small value. The results of the procurement and value of soil elements, climate produces a climate land index with the following equation:

$$
\mathrm{I}=\mathrm{A} \times \mathrm{B} / 100 \times \mathrm{C} / 100 \times \mathrm{D} / 100 \times \ldots . \mathrm{N} / 100
$$

Note:

$\mathrm{I}=$ land index/climate $\mathrm{A}, \mathrm{B}, \mathrm{C}$,

$\mathrm{N}=$ critical characteristic value of each land / climate.

Plant land suitability can be used by many methods or evaluations of classes of land suitability, such as the parametric approach provided. This approach is based on land index values and limiting factors so that the valuation of data approaches detail and allows subjective judgments to be avoided.

\section{RESULTS AND DISCUSSION}

\subsection{Value, index and land suitability class of arabica coffee plants}

The weight of each climate and Arabica coffee land characteristics (Coffea arabica L.) was obtained by combining the climate and land characteristics with the plant growth requirements. Limiting factor that was without a limitation to a very severe limitation by granting each value from a maximum value (100) to a minimum (0). While the land index and climate were a multiplication of each character or quality of land with a valuated climate.

According to the requirements needed by Arabica coffee plant (Coffea arabica L.) is presented in Table 1. Then the land of the research area in the Pasang Village corresponds to marginal with a medium limiting level (S3) with a land index value of 32.21 limiting factors, namely the slope. High slope will reduce land index and land suitability class [12]. While the research area of the Parindingan Village was quite appropriate (S2) with a land index value of 50.12 and did not have a moderate barrier.

It was due to Arabica coffee plants in the Pasang Village, Dendeng Piongan Napo Subdistrict' are cultivated on sloping land area. So that the growth of Arabica coffee plants was not comparable with the growth of coffee plants in the area Parindingan Village, Gandang Batu Sillanan Subdistrict. The steeper and longer the slope will increase the surface flow velocity and the greater water surface volume so that more objects are transported [13].

Arabica coffee grows optimally at 1000-1700 meters above sea level [14]. The height of the place affects the difference in the slope [15]. The optimal slope for Arabica growth is $2-8 \%$, while $>8 \%$ growth is inhibited due to erosion resulting from objects displacement on the surface $[16,17]$. The steeper slope conditions cause the influence of gravity in moving materials from the slope is getting bigger too. If the process occurs at a slope of more than $8 \%$, the surface flow will increase in number and speed as the slope becomes steeper. Thus, continuous erosion leads the soils to become shallow solum, low organic matter content, high soil density, and low soil porosity compared to soils in flat areas with deep groundwater. The difference slope causes the difference in the amount of available water for plants that might affect the vegetation growth in that place [18].

Table 1. Index value and land suitability class in Arabica Coffee Plant (Coffea Arabica L.) on research location

\begin{tabular}{ccc}
\hline \multirow{2}{*}{ Land Characteristics } & \multicolumn{2}{c}{ Research Location } \\
\cline { 2 - 3 } & Pasang Village & Parindingan Village \\
\hline Climate & 73 & 78 \\
Slope & 82 & 93 \\
Flood & 100 & 100 \\
Drainage & 100 & 100 \\
Texture & 90 & 95 \\
Solum depth & 96 & 97 \\
Surface Rock & 97 & 100 \\
CEC & 92 & 95 \\
Base Saturation & 95 & 96 \\
pH H ${ }_{2} 0$ & 95 & 97 \\
Organic - C & 90 & 95 \\
N-Total & 92 & 93 \\
$\mathrm{P}_{2} \mathrm{O}_{5}$ (HCL 25\%) & 93 & 95 \\
$\mathrm{~K}_{2} \mathrm{O}$ (HCL 25\%) & 92 & 96 \\
\hline Land Index & 32.21 & 50.12 \\
\hline Suitability Land Classes & $\mathrm{S3}$ & $\mathrm{S} 2$ \\
\hline
\end{tabular}

3.2 Relationship between land index and Arabica coffee production

Regression analysis results show there is a linear 
relationship between land index and production $(\mathrm{Y}=2 \mathrm{x}+4)$ with a correlation value R2 $=1$ (Figure 1 ). Table 2 shows that Village Parindingan has a higher Land Index that is 50.12 compared to Village Pasang which is 32.21. A high land index indicates a higher level of production where Peridingan village has the potential to produce Arabica Coffee up to 8 tons / Ha.
Thus, Parindingan Village has more potential for the development of Arabica Coffee in Tanah Toraja Regency. It reflects that there is a close relationship between the land index and production. A high land index tends to provide high production, and vice versa, a low land index shows small production as well [6].

Table 2. Representative profile of land index and production of Arabica coffee (Coffea arabica L.) at two research locations in Tanah Toraja Regency

\begin{tabular}{ccccc}
\hline Profile codes & Subdistrict & Village & Land Index & Production level (ton/Ha) \\
\hline P1 & Dendeng Piongan Napo' & Pasang & 32.21 & 6 \\
P2 & Gandang Batu Sillanan & Parindingan & 50.12 & 8 \\
\hline
\end{tabular}

The results of the study in the Pasang Village gained an appropriate marginal (S3), the land and climate in the study locations considered appropriate. Unfortunately, Slopes are not suitable, so it affects the production of arabica coffee. Whereas arabica coffee plants in Parindingan Village are considered to be quite suitable (S2), land and climate considered suitable to support arabica coffee production. The rainfall on steep slopes will cause erosion, so that dry branches or leaves of plants have no time to decompose on the ground. Dry branches are expected to decompose and become an organic matter that is absorbed by the roots for plant growth [13].

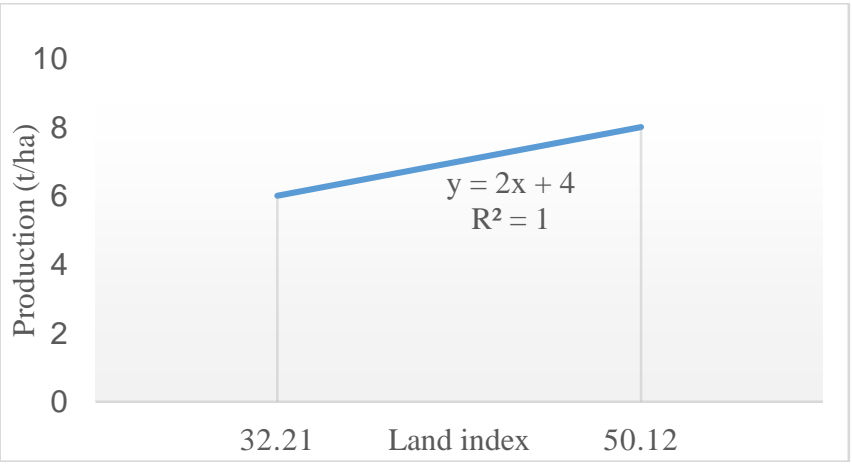

Figure 1. Relationship between land index and Arabica coffee production in two research locations in Tana Toraja

Slopes affect erosion in relation to the steepness and length of the hill. Land with $30-45 \%$ of the steep slope has a more significant gravity influence than the area with $15-30 \%$ and 8 $15 \%$ steep slope. This is due to the greater gravity in line with the sloping ground surface from the horizontal plane. This gravity is an absolute requirement for detachment, transportation, and sedimentation [19]. In the slope, the steeper the hill, the higher the surface flow where the soil contains a lot of organic material will be transported and carried to a lower place, which can affect the growth of the surrounding vegetation. The steeper the slope will increase the number and speed of surface flow, to increase energy and be able to increase the ability to transport soil grain [20].

Furthermore, poor management, low soil fertility and low prices are considered to be major coffee production constraints [21]. Climate change is also expected to have a strong effect on population dynamics and the status of farm insect pests and disease development. Temperature increase has a strong and direct impact on insect growth, reproduction and survival [22]. Maintenance factors can also influence the low production of coffee plants [23]. Coffee plants with a lack of maintenance will get lower output compared to maintained coffee plants in accordance with the conditions of the growth. In maintaining coffee plants in the crops, of course, intensive care must be taken, such as weeding or controlling the growth and development of weeds around the coffee plant. Grass should be removed because it can interfere with the coffee plants in absorbing nutrients. Besides, weeding aims to facilitate maintenance [24].

\subsection{Relationship of optimal production and suitability land classes}

Table 4 shows the land suitability classes and production of Arabica coffee plants (Coffea Arabica L.) according to an optimum production shown in Table 3. It can be seen that the highest Arabica coffee production was found in the area of Parindingan Village with an amount of 8 tons / Ha, obtaining sufficient production value accordingly (S2). Whereas the lowest production was in the location of Pasang Village with the amount of 6 tons / Ha of production obtained an appropriately marginal (S3). Besides that, the land and climate of Parindingan Village were considered to be very suitable (S1), and Pasang Village was quite appropriate (S2).

Table 3. Relationship between optimum production of Arabica coffee (Coffea arabica L.) and land suitability class

\begin{tabular}{cc}
\hline Production Index & Optimum Production Index (ton/Ha) \\
\hline$>75$ & $>14$ \\
$50-75$ & $8-14$ \\
$25-50$ & $4-8$ \\
$12-25$ & $2-4$ \\
$<12$ & $<2$ \\
\hline
\end{tabular}

Table 4. Production range of Arabica coffee (Coffea Arabica L.) at various levels

\begin{tabular}{cc}
\hline Levels & (ton/Ha) \\
\hline Optimum & 14 \\
Marginal & 8 \\
Unprofitable & 2 \\
\hline
\end{tabular}

Based on the suitability of production classes obtained from two marginal locations (S3). Production of both is not said to be optimum production. It may due to environmental factors such as maintenance factors that farmers pay less attention to weeding, pruning, fertilizing, and harvesting. Behind that, the land condition also influences the production of coffee plants such as inhibiting factors, namely the slope in the Pasang Village [16].

Regarding the slope, the steeper the slope, the greater the surface flow where the soil that contains a lot of organic 
material will be transported and carried to a lower place. Low organic matter content, a high level of soil density, and low soil porosity compared to soils in flat areas with deep groundwater. The difference slope causes a difference in the amount of water available to plants, thereby affecting the growth of vegetation and crop production in that place [25], [26].

In the maintenance of coffee plants in the plantation, intensive care must be taken, such as weeding activities, which are maintenance activities to get rid of or control the growth and development of weeds around the coffee plantations. In addition, weeding aims to facilitate maintenance actions such as fertilization, pruning, and harvesting [27]. Fertilization is the main activity that must be carried out in the cultivation of coffee plants [28]. Coffee plants will not be able to produce optimally if the food supply is reduced, for that by doing fertilization leads a lot of fruiting coffee plants [27].

The pruning activity is divided into three types, including form pruning, which is executed on immature plants to form a balanced branching and forming a plant framework such as canopy shape, plant height, and branching type. Next is the production pruning, which is done on plants that are already in production in order to get new primary branches so as to increase the fruit production. Pruning the unproductive branches or old branches is done on plants focus more on growing productive branches [29].

\subsection{Economic analysis of Arabica coffee based on land suitability class farmer level}

Coffee originating from the island of Sulawesi, called "Toraja coffee" has a unique characteristic, has a strong aroma and a very special physical characteristic that is heavy seeds [30]. The economic analysis results of Arabica coffee (Coffea arabica L.) in Table 5 obtained $\mathrm{R} / \mathrm{C}$ ration ranging from 4.41 to 6.02. This value was greater than one; thus, both locations in North Toraja Regency and Tana Toraja Regency were eligible for arabica coffee plantation business. At the location of Arabica coffee plantations (Coffea arabica L.) in Pasang Village were rated S3 (appropriate marginal terms), the farmer's net income is IDR. 129,900,000, while Parindingan Village was assessed S2 (quite appropriate), net income was higher at IDR. 186,797,000. The low production of farmers' severe income was due to the slope and maintenance factors [31].

Table 5. Economic analysis of Arabica coffee based on land suitability class farmer level

\begin{tabular}{|c|c|c|c|}
\hline \multicolumn{4}{|c|}{ The Usage of Arabica Coffees Land } \\
\hline & Location & $\mathrm{P} 1$ & $\mathrm{P} 2$ \\
\hline & Suitability Land Classes & S3 & S2 \\
\hline \multirow[t]{4}{*}{ I. } & Production Cost & & \\
\hline & A. Labor (IDR) & $31,025,000$ & $3,635,000$ \\
\hline & $\begin{array}{l}\text { B. Production Facilities } \\
\text { (IDR) }\end{array}$ & $4,075,000$ & $2,568,000$ \\
\hline & C. Others (IDR) & & \\
\hline II. & Production $(\mathrm{kg})$ & 6,000 & 8,000 \\
\hline III. & Basic Cost (IDR/Kg) & $6,350,000$ & $4,650,345$ \\
\hline \multirow[t]{3}{*}{ IV. } & Production Value & & \\
\hline & A. Field Price (IDR/Kg) & 28,000 & 28,000 \\
\hline & B. Gross Profit (IDR/Ha) & $168,000,000$ & $224,000,000$ \\
\hline \multirow[t]{4}{*}{$\mathrm{V}$} & Farmers profits & & \\
\hline & A. Net Price (IDR/Kg) & $21,650,000$ & $23,349,625$ \\
\hline & B. Net Profit (IDR/Kg) & $129,900,000$ & $186,797,000$ \\
\hline & $\mathrm{R} / \mathrm{C}$ & 4.41 & 6.02 \\
\hline
\end{tabular}

Land productivity and Arabica coffee plants are largely determined by the quality of the land with the support of the availability of farmers who master cultivation technology. Economically, Arabica coffee plants can only be cultivated in mountainous areas [32]. But with the location of the mountains the biggest challenges faced are the availability of labor (farmers) where the population is decreasing, and the lack of available infrastructure and means of transportation, so that high capital is needed to build road infrastructure, open residential land, and transport facilities and production [33].

The strategy used in increasing Arabica coffee production is to increase land allocation to balance the high demand for Arabica coffee and to increase farmers' incomes [34]. Then, use counseling to improve the quality of farmers [35], the application of technology [36], pest and disease control [37], and better post-harvest handling [38].

\section{CONCLUSIONS}

Land suitability class and land index in Pasang Village are appropriately marginal (S3) and land index 32.12 with the main limiting factor is slope while in Parindingan Village has a moderate barrier so that the suitability class is quite appropriate (S2) and land index 50.12. There is a linear relationship between the land index and Arabica coffee production; the higher the land index, the higher production obtained.

The analysis of the economy on Arabica coffee crops at two locations in each Pasang and Parindingan Village obtained a net profit of IDR 129,900,000 - IDR 186,797,000 with R/C ration value $>1$, i.e., $4.41-6.02$, the Arabica coffee business is worth to continue.

\section{ACKNOWLEDGMENTS}

Thank you to the Dean of Faculty of Agriculture, Tadulako University for funding the implementation of this research so that this research could be completed as expected.

\section{REFERENCES}

[1] Sys, C., Van Ranst, E., Debaveye, J. (1991). Land Evaluation. Part I: Principles in Land Evaluation Land Crop Production Calculitions. Agricultural Publications nr. 7, G.A.D.C, Brussels, Belgium, 1991.

[2] FAO. (1976). A Framework for Land Evaluation. FAO Soil Bulletin, vol. 32, 1976.

[3] Sys, C., Van Ranst, E., Debaveye, J., Beernaert, E. (1993). Land Evaluation. Part III: crop requirements. Agricultural Publications $\mathrm{n}^{\circ}$ 7, G.A.D.C., Brussels, Belgium, 1993, $191 \mathrm{p}$.

[4] Salima, R., Karim, A., Sugianto, S. (2012). Evaluasi kriteria kesesuaian lahan kopi arabika gayo 2 di dataran tinggi gayo. Jurnal MSDL, 1(2): 194-206.

[5] Wezel, A., Steinmüller, N., Friederichsen, J.R. (2002). Slope position effects on soil fertility and crop productivity and implications for soil conservation in upland northwest Vietnam. Agriculture, Ecosystems \& Environment, $\quad 91(1-3)$ : 113-126. https://doi.org/10.1016/S0167-8809(01)00242-0

[6] Neswati, R., Lopulisa, C., Nathan, M., Ramlan, A. 
(2017). Land suitability index for estimating sugar cane productivity in the humid tropics of South Sulawesi Indonesia. Journal of Tropical Soils, 21(2): 115-122. https://doi.org/10.5400/jts.2016.v21i2.115-122.

[7] Basir, A., Neswati, R., Baja, S., Lopulisa, C. (2018) Climate index for estimating nutmeg plant suitability under tropical rainforests in Maluku Province, Indonesia. International Journal of Agriculture and Environmental Science, $5(6)$ 23-30. https://doi.org/10.14445/23942568/IJAES-V5I6P105

[8] Hartono, B., Rauf, A., Elfiati, D., Harahap, F.S. Sidabuke, S.H. (2018). Evaluasi kesesuaian lahan pertanian pada areal penggunaan lain untuk tanaman kopi Arabika (Coffea Arabica L.) Di kecamatan salak kabupaten pak-pak bharat. Jurnal Solum, 15(2): 66. https://doi.org/10.25077/jsolum.15.2.66-74.2018.

[9] Arief, M.C.W., Tarigan, M., Saragih, R., Lubis, I., Rahmadani, F. (2011). Panduan Sekolah Lapangan: Budidaya Kopi Konservasi, Berbagi Pengalaman Dari Kabupaten Dairi Sumatera Utara. Conservation International Indonesia

[10] Rubiyo, J., Rinaldi, R., Suharyanto, S. (2003). Kajian Rehabilitasi Tanaman Kopi Robusta dengan Kopi Arabika dengan Teknik Sambung di Kabupaten Bangle Bali. Pengkajian Teknologi Pertanian Bali.

[11] Mandal, V.P., Rehman, S., Ahmed, R., Md. Masroor, Kumar, P., Sajjad, H. (2020). Land suitability assessment for optimal cropping sequences in Katihar district of Bihar, India using GIS and AHP. Spatial Information Research. https://doi.org/10.1007/s41324-020-00315-z

[12] Abdel Rahman, M.A.E., Natarajan, A., Hegde, R. (2016). Assessment of land suitability and capability by integrating remote sensing and GIS for agriculture in Chamarajanagar district, Karnataka, India. The Egyptian Journal of Remote Sensing and Space Science, 19(1): 125-141. https://doi.org/10.1016/j.ejrs.2016.02.001

[13] Martono, M. (2004). Pengaruh Intensitas Hujan dan Kemiringan Lereng Terhadap Laju Kehilangan Tanah Pada Tanah Regosol Kelabu. Master thesis, Program Pascasarjana Universitas Diponegoro.

[14] Siahaan, Ir.A. (2018). Identification of Arabica coffee production in altitudes place in Lintong $\mathrm{Ni}$ Huta of Humbang Hasundutan. International Journal of Environment, Agriculture and Biotechnology, 3(1): 249255. https://doi.org/10.22161/ijeab/3.1.31

[15] Fenton, G.A., Hicks, M.A., Wang, X., Griffiths, D.V. (2013). Effect of slope height and gradient on failure probability. in Geo-Congress 2013, San Diego, California, United States, pp. 972-981. https://doi.org/10.1061/9780784412787.099

[16] Arvi, D., Syakur, S., Karim, A. (2020). Hubungan ketinggian tempat dan kelerengan terhadap produksi kopi arabika gayo 1 di kabupaten gayo lues. JIMFP, 4(4): 596602. https://doi.org/10.17969/jimfp.v4i4.12826

[17] Budiman, H. (2012). Prospek Tinggi Bertanam Kopi Pedoman Meningkatkan Kualitas Perkebunan Kopi. Yogyakarta: Pustaka Baru Press.

[18] Hardjowigeno, S. (1993). Klasifikasi Tanah dan Pedogenesis. Jakarta: Akademika Pressindo, 1993.

[19] Jawang, U.P., Simanjuntak, B.H., Prihtanti, T.M. (2018). Evaluasi kesesuaian lahan komoditas unggulan perkebunan kecamatan katiku tana selatan kabupaten sumba tengah. Journal of Natural Resources and Environmental Management, 8(3): 396-405 https://dx.doi.org/10.29244/jps1.8.3.396-405

[20] Widiatmaka, W., Ambarwulan, W., Mulia, S.P., GintingSoeka, B.D., Bondansari, B. (2014). Evaluasi lahan fisik dan ekonomi komoditas pertanian utama transmigran di lahan marjinal kering masam rantau pandan $\mathrm{Sp}-4$, provinsi jambi. Journal of Natural Resources and Environmental Management, 4(2): 152-160.

[21] Tadesse, T., Tesfaye, B., Abera, G. (2020). Coffee production constraints and opportunities at major growing districts of southern Ethiopia. Cogent Food \& Agriculture, $\quad 6(1)$ : 1741982. https://doi.org/10.1080/23311932.2020.1741982

[22] Ward, N.L., Masters, G.J. (2007). Linking climate change and species invasion: An illustration using insect herbivores. Global Change Biology, 13(8): 1605-1615. https://doi.org/10.1111/j.1365-2486.2007.01399.x

[23] Rahmanta, Purba, S., Supriana, T. (2019). Factors affecting the production of arabica coffee of smallholder plantations in Dairi District. IOP Conference Series: Earth and Environmental Science, 260: 012007. https://doi.org/10.1088/1755-1315/260/1/012007

[24] Dermawan, S.T., Mega, I.M., Kusmiyarti, T.B. (2018). Evaluasi kesesuaian lahan untuk tanaman kopi robusta (coffea canephora) di desa pajahan kecamatan pupuan kabupaten tabanan. E-Jurnal Agroekoteknologi Tropika, 7(2): 230-241.

[25] Korah, T., Turangan, A.E., Sarajar, A.N. (2014). Analis kestabilan lereng dengan metode janbu (studi kasus: kawasan citraland). Jurnal Sipil Statik, 2(1): 51-75.

[26] Mardhiah, M., Akhmad, B., Safrida, S. (2020). FaktorFaktor yang Mempengaruhi Ekspor Kopi di Aceh. Jurnal MSDL, 5(2): 192-202.

[27] AAK. (1991). Budidaya Tanaman Kopi. Jogjakarta: Penerbit Kanisius.

[28] Gonthier, D.J., Witter, J.D., Spongberg, A.L., Philpott, S.M. (2011). Effect of nitrogen fertilization on caffeine production in coffee (Coffea arabica). Chemoecology, 21(3): 123-130. https://doi.org/10.1007/s00049-0110073-7

[29] Silaban, S.H., Sitorus, B. Marbun, P. (2016). Evaluasi kesesuaian lahan untuk tanaman kopi arabika (coffea arabica), kentang (solanum tuberosum 1.) kubis (Brassica oleraceae L.) Dan Jeruk. Jurnal Online Agroekoteknologi, 4(3): 2055-2068.

[30] Prasetyawati, D., Dharma, R., Kadir, R. (2017). The marketing strategy of coffee in Tana Toraja. International Journal of Science and Research (IJSR), 6(11): 953-958. https://doi.org/10.21275/ART20178036

[31] Caesara, V., Usman, M., Baihaqi, A. (2017). Analisis pendapatan dan efisiensi pemasaran biji kopi (green bean) arabika di kabupaten bener meriah. JIMFP, 2(1): 250261. https://doi.org/10.17969/jimfp.v2i1.2306

[32] Wahyudi, T., Jati, M. (2012). Challenges of sustainable coffee certification in Indonesia. in Seminar on the Economic, Social and Environmental Impact of Sertification on the Coffee Supply Chain, London, 2012, 109: $1-14$.

[33] Tanan, A. (2012). Strategi pengembangan agribisnis kopi arabika di tana toraja. AgroSainT UKI Toraja, 3(2): 308318 .

[34] Sarirahayu, K., Aprianingsih, A. (2018). Strategy to improving smallholder coffee farmers productivity. The Asian Journal of Technology Management (AJTM), 11(1): 1-9. https://doi.org/10.12695/ajtm.2017.11.1.1 
[35] Tuningrat, I.A.M., Satriawan, K., Darmawan, D.P., Wiranatha, A.A.P.A. (2019). The development of robusta coffee agroindustry system in Bali based on structural analysis and institutional interaction. Bali, Indonesia, 2155(1):

020047. https://doi.org/10.1063/1.5125551

[36] Bliska, F., Turco, P., Tosto, S., Fronzaglia, T., Vegro, C. (2013). Impact of technological innovations for coffee production in adverse weather conditions. ERSA conference papers ersa13p1188, European Regional Science Association.

[37] Waller, J.M., Bigger, M., Hillocks, R.J. (2007). Coffee Pests, Diseases and Their Management. Wallingford, UK; Cambridge, MA: CABI Pub., 2007.

[38] Haile, M., Kang, W.H. (2019). The Harvest and PostHarvest Management Practices' Impact on Coffee Quality. Coffee - Production and Research. https://doi.org/10.5772/intechopen.89224 